International Journal of Health Sciences
Available online at www.sciencescholar.us
Vol. 6 No. 1, April 2022, pages: 234-243
e-ISSN: 2550-696X, p-ISSN: 2550-6978
https://doi.org/10.53730/ijhs.v6n1.3870

\title{
Modern Learning Models through Teacher and Student Dynamic Interaction in HEI towards COVID-19 Pandemic Condition
}

\author{
(1) CrossMark

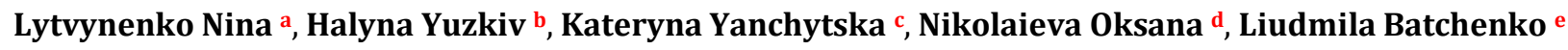 \\ Manuscript submitted: 14 September 2021, Manuscript revised: 18 December 2021, Accepted for publication: 8 January 2022
}

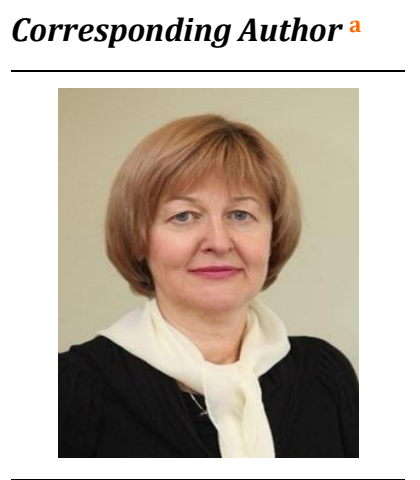

Keywords

COVID-19 pandemic; educational digital content, educational process; higher education system; higher educational institutions; online learning; teacher-student interaction

\begin{abstract}
The aims of the study is an empirical assessing the dynamic interaction of a teacher and a student at the HEI during a pandemic as an important component of the distance learning model, identifying methods and ways to ensure the integration of this component in the distance learning program for further use in the practice of HEIs. The methodology is based on the method of case analysis of the University of Oxford in the organization of educational activities during the pandemic following the Business Continuity Planning (BCP) framework. The results show that planning of crises should be used and, accordingly, scenarios for organizing educational activities should be developed for the effectiveness of the digital learning model and the provision of a dynamic online environment. It has been revealed that the University of Oxford's Business Continuity Planning (BCP) framework provides insight into the current crisis. The next factor in the effectiveness of training at HEIs during a pandemic is the planning of training courses based on templates developed by the leadership of universities. Templates of hybrid, virtual, personal courses provide unified teaching and learning processes, greatly facilitating the interaction of students and teachers.
\end{abstract}

International Journal of Health Sciences (C) 2022. This is an open access article under the CC BY-NC-ND license (https://creativecommons.org/licenses/by-nc-nd/4.0/).

\section{Contents}

Abstract

1 Introduction..

2 Materials and Methods

a Bogomolets National Medical University, Kyiv, Ukraine

b Bogomolets National Medical University, Kyiv, Ukraine

c Bogomolets National Medical University, Kyiv, Ukraine

d Bogomolets National Medical University, Kyiv, Ukraine

e Kyiv National University of Culture and Arts, Kyiv, Ukraine 


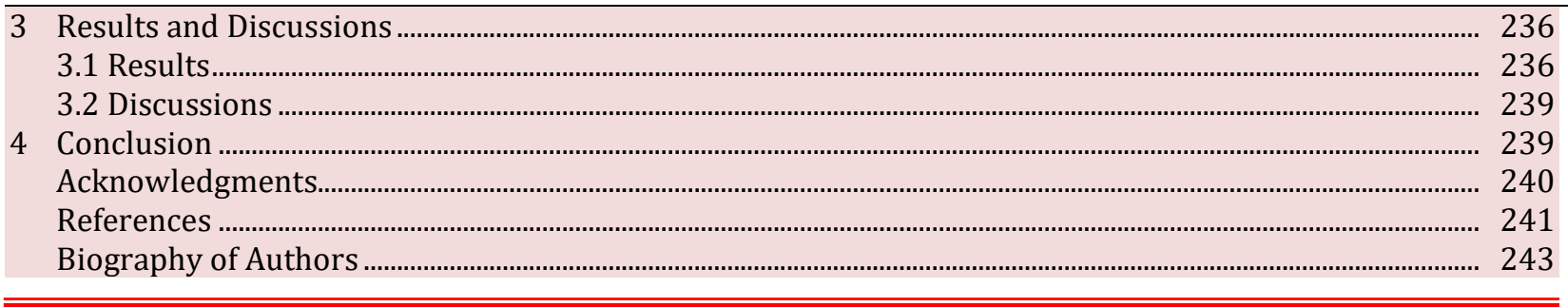

\section{Introduction}

For the higher education system, in particular, changing the paradigm of blended learning, transforming models of higher educational institutions (HEIs) through the need for an immediate digital response. In the first instance, students have realized the benefits of traditional models of learning with the possibility of direct contact with all participants in the educational process (Petronzi \& Petronzi, 2020).

Despite the introduction of blended learning models in higher education in different countries, challenges emerged during the pandemic process. The major problems are as follows: the lack or insufficient level of infrastructure development; insufficient level of teachers' experience, which has affected the quality of education; lack of clear information about the learning environment during the pandemic, which has led to the complexity of the educational process for different participants, reducing the level of motivation during learning at home; the need for rapid development of educational digital content and it's adapting to the new learning environment (Ramírez-Hurtado et al., 2021; Cicha et al., 2021). The basic problems of the transition to virtual classes of HEIs were network problems, lack of training, and insufficient awareness of teachers (Arora \& Srinivasan, 2020; Arianggara et al., 2021). As a result of the problems outlined, the level of interest in online education, innovations are decreasing; many doubts arise concerning the use of virtual classes; a problem is also observed.

Large and most developed universities have adapted most effectively to changes due to technological advantages and financial resources. Only available university resources can effectively transform classical education into online education through expansion, creating a virtual learning environment (Mishra et al., 2020). Although it has been noted in the scientific literature (Ramírez-Hurtado et al., 2021).

Lack of interactivity, the dynamic interaction between students, between teachers and students, is one of the problems of full transition to a digital learning environment, achievement of educational goals (Ferri et al., 2020; Verawardina, 2020; Ramírez-Hurtado et al., 2021). This problem reduces the level of motivation and satisfaction with online teaching; it actualizes the need to study the best practices for its subsequent solution.

The purpose of the academic paper lies in empirical assessing the dynamic interaction of a teacher and a student at the HEI during a pandemic as an important component of the distance learning model, identifying methods and ways to ensure the integration of this component into a distance learning program for further use in the practice of HEIs (Graham et al., 2013; Alkhalaf et al., 2012).

\section{Literature review}

In the scientific literature, the issue of learning models and mixed approaches has become especially popular during the period of the spread of the pandemic and quarantine restrictions. Yuzkiv et al. $(2020 ; 2021)$, explore the practice of studying language disciplines, based on methods of meaningful and languageintegrated learning, as well as methods of using digital technologies. Petronzi \& Petronzi (2020), investigate mixed approaches to key pedagogical and learning theories to develop their own "Online and Campus (OaC) model" as a potential "plan" for student-oriented, asynchronous (flexible, autonomous) and synchronous learning mode (Slipchuk et al., 2021). Synchronous learning mode means a learning environment in which students are at the same time in one place (online or on-campus) with equal access to the same materials.

Cicha et al. (2021), Rizun \& Strzelecki (2020), study the perception by Polish students of the GETAMEL learning model - an adapted general expanded model of technology adoption in the conditions of e-learning. Scientists argue that simplicity and convenience provide satisfaction with distance education, and as a result, self-efficacy of students in Poland. The results of the investigation of Ramírez-Hurtado et al. (2021),

Nina, L., Yuzkiv, H., Yanchytska, K., Oksana, N., \& Batchenko, L. (2022). Modern learning models through teacher and student dynamic interaction in HEI towards COVID-19 pandemic condition. International Journal of Health 
concerning assessing the quality of online teaching during COVID-19 at the University of Southern Spain have identified five priority attributes of online teaching. These attributes are as follows: interaction of students, levels of concentration in online learning, online tests review system, usefulness, diversity of assessment test. Ramírez-Hurtado et al. (2021), recommend changing the online format of training at HEIs, integrating methodological and technological solutions into this format that promote cooperation between teachers, students, and administrative staff.

Mittal et al. (2021), have developed a theoretical model highlighting the determinants of the implementation of online teaching during the COVID-19 outbreak, in particular, the importance of the adoption and practical use of technology by teachers in the process of training. Along with this, the important determinants of the success of digital learning models are leadership promotion, regulatory support, the ability of the project team to implement the online learning model in practice (Iglesias-Pradas et al., 2021; Chang et al., 2020; Sá \& Serpa, 2020).

Bao (2020), based on the case of the University of Beijing, has identified six elements of learning to improve the concentration and engagement of students towards achieving a smooth transition to online learning. The principal components of strategies are as follows: the formation of an emergency preparedness plan, the transfer of courses into online mode; division of educational material to increase the concentration of students based on modules; the importance of interaction (body language, gestures of teachers) as a tool to attract and motivate students; technical support for teachers, including training and support when working on online platforms; introduction of new methods of attracting students to study outside the online classes; an effective combination of online learning and offline self-education (Díaz-Campo \& Segado-Boj, 2015; Claro et al., 2018).

In the scientific works of Tirziu \& Vrabie (2015), Thai et al. (2017), Asarta \& Schmidt (2020), Ożadowicz (2020), the main models of learning based on e-learning and distance learning methods have been considered, providing different ways of dynamic interaction between the teacher and the student. Thus, the issue of learning models with the use of digital solutions has become especially relevant at HEIs under the conditions of the pandemic; the challenge of ensuring the effectiveness of the dynamic interaction of a teacher and a student to achieve educational goals is of particular importance (Andrew \& Pfurtscheller, 1996; Gerlich et al., 2006).

\section{Materials and Methods}

The qualitative content analysis has been used in the present research to assess the Oxford University learning model. For conducting the analysis, the case method has been used based on official information about learning models posted on the websites of HEIs. In particular, detailed information from the information resources of the Center for Teaching and Learning has been studied (Oxford University, 2021a), Flexible and Inclusive Teaching (Oxford University, 2021b). The latter contains information about the organized distance learning model with asynchronous and synchronous modes of training activities of teachers.

\section{Results and Discussions}

\subsection{Results}

A contingency plan has been developed and established in Oxford, providing the organization of training depending on the expectations of the pandemic and its consequences. The plan provides some scenarios for the organization of the educational process depending on the emergency; however, the university aims to ensure the highest standards of education regardless of the impact of the COVID-19 pandemic). For instance, on December 15, 2021, the university has moved to the 2nd level of business continuity planning.

In the 2021-2022 academic year, Oxford has supported a model of flexible and inclusive teaching, encouraging a flexible and inclusive approach to learning. The chosen approach reflects personalized highquality education of the HEI, supporting teachers and students in times of crisis, including through instant 
information support. Consequently, the dynamic interaction of the teacher and the student is formed (Lyster, 2002; Van de Pol \& Elbers, 2013).

Practice shows that direct interaction through traditional teaching methods is the most effective; after all, the universities plan to return to personal training in 2022 (using textbooks, seminars, and classes, laboratory, effective and practical activities). Fieldwork and research abroad will also resume (subject to restrictions on international travel). Oxford also provides measures to meet the educational needs of students who must self-isolate or cannot return to the UK. In particular situations, this means teaching in a hybrid format. During the pandemic, within Oxford, the most successful online teaching innovations for the 2020-21 academic year have been created.

The information on support and provision of guidance for teachers in the 2021-22 academic year has been published on the website of the Center for Teaching and Learning (CTL). Recommendations include as follows: tips on flexible and inclusive learning, instructions on distance learning, planning and presentation of a hybrid training session, availability, training and webinars, specific pieces of advice on teaching under the conditions of the pandemic, according to University documents on teaching and assessment in case of emergencies.

Oxford's Flexible and Inclusive Training (FIT) has ensured technical and technological support to teachers to provide full involvement and participation of the stakeholders in the learning process, similar to traditional classes. Inclusive learning means primarily identification and minimizing barriers, obstacles to learning, as well as the participation of students. Flexible learning focuses on the students' needs, taking into account the place, time, and methods of training activities (Savinova et al., 2021; Estevez et al., 2019).

Technical and technological support has solved the problem of dynamic interaction between teachers and students in conditions of limited access and lack of awareness of digital learning technologies. Since a unified platform for interaction was created in Oxford, teachers were able to quickly share experiences and possible problems with the use of technology, contributing to the positive perception and development of learning platforms. All teachers continued to conduct classical classes: laboratory works, lectures, and works in small groups of two types, consultations for students. According to traditional lessons, the university leadership proposed scenarios for a training course for teachers.

Each of the classic classes reflects the possibility of combining asynchronous and synchronous learning modes to provide a greater level of flexibility in the interaction of students and teachers, the concentration of participants in the learning process in "real-time" in the place of the greatest value of teaching. The HEI has also provided the opportunity to use various digital tools during teaching, conducting practical classes depending on the learning scenario. The teacher was able to combine the most effective tools for his course to solve specific problems and achieve the desired outcomes (Lytvyn et al., 2021; Widana et al., 2021).

The process of organizing Oxford's laboratory work is based on a flexible and inclusive approach. Therefore, the HEI has predetermined the technologies that will be used by university teachers, depending on the stage of the course. At the stage of the presentation of the course, the teachers used the Panopto program with the possibility of asynchronous or synchronous reviewing by students. Along with this, the Teams program was used at the stage of actual laboratory work in hybrid, traditional or virtual conditions; the Canvas program was used at the stages of assessing results, discussions, and assignment of homework. The stage of the actual laboratory class should be synchronized.

Nina, L., Yuzkiv, H., Yanchytska, K., Oksana, N., \& Batchenko, L. (2022). Modern learning models through teacher and student dynamic interaction in HEI towards COVID-19 pandemic condition. International Journal of Health Sciences, 6(1), 234-243. https://doi.org/10.53730/ijhs.v6n1.3870 


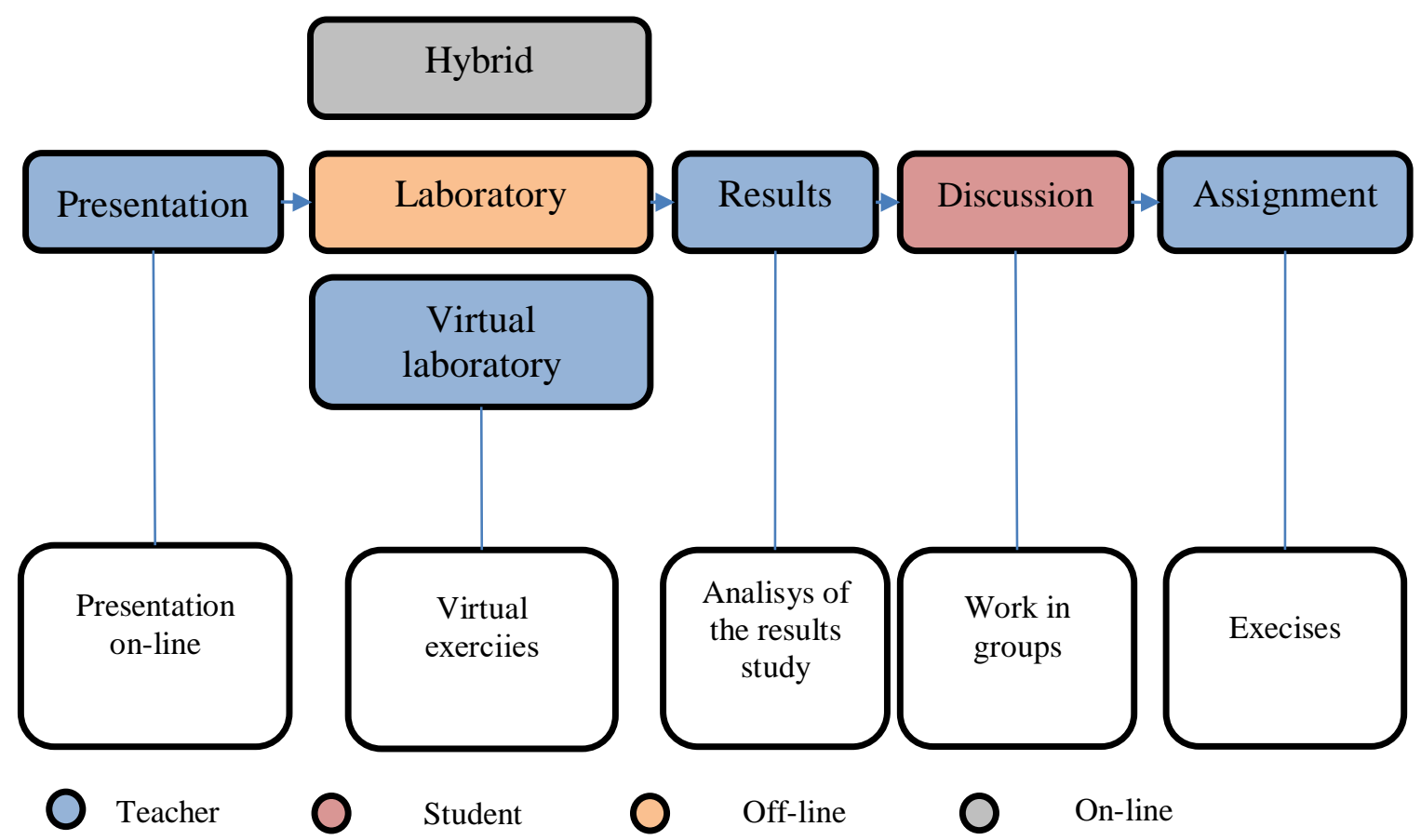

Figure 1. The process of organizing the laboratory class in Oxford during the pandemic

The process of organizing lectures was somewhat different from the process of laboratory classes, in particular, in terms of the possible digital tools offered to teachers. At the presentation stage, teachers used the Panopto tool, at the discussion stage - the Canvas program was applied; at the stages of interaction, communication - the Teams program; at the Polling stage - the Vevox program was used. The stages of interaction and Polling were to be synchronized, while the presentation and discussion could be asynchronous.

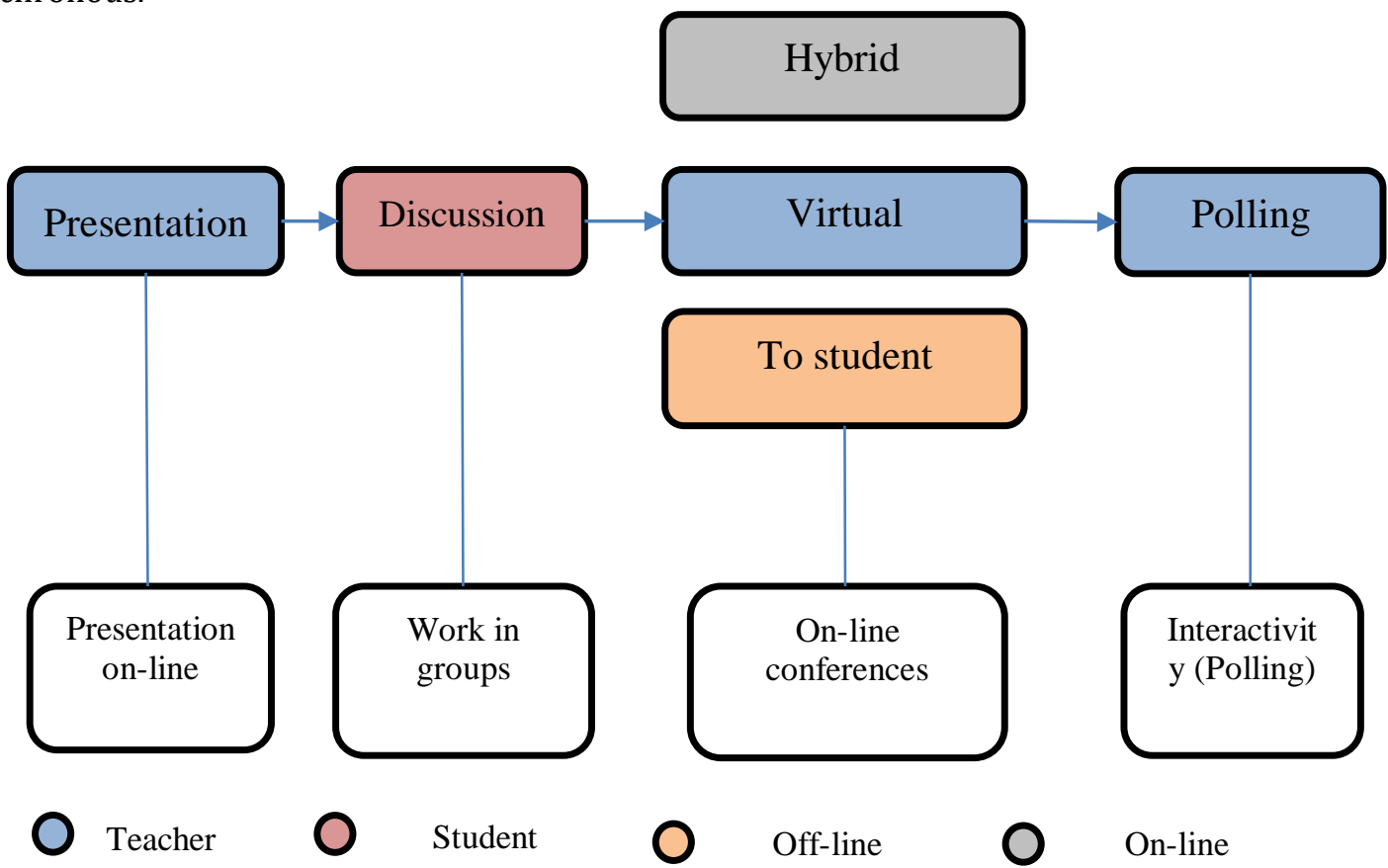

Figure 2. The process of organizing a lecture in Oxford during the pandemic Source: Oxford University (2021b) 
Thus, the learning model provided dynamic interaction at each stage with potentially maximum involvement of students in the process. Support for tutors included registration with FIT Canvas, provision of Canvas templates pre-designed for the online learning environment, provision of assistance to teachers on the part of support consultants (Moore et al., 2011; Dağ \& Geçer, 2009). Therefore, Oxford has ensured the unification of teaching through a flexible, inclusive approach. The uniform training standards and technologies used in teaching are complemented by the ability of teachers and students to choose the time, place of interaction, as well as training methods. Such an approach has helped the course teams conceptualize the processes of adapting existing teaching practices to new training methods; it has provided flexibility to quickly move to more distant or more personalized learning, depending on the circumstances (Diachenko et al., 2021).

FIT technologies have been used by educators as models for the transition from personal to distance learning model according to students' needs. The technologies have also helped divide the classes into significantly shorter segments to avoid the problem of decreasing students' engagement rates, which is especially noticeable during offline lectures. Teachers have also been able to save time for developing courses and digital content with the application of Canvas templates.

\subsection{Discussions}

In the course of the research, it has been revealed that technical, technological support for a digital learning model based on a flexible, inclusive approach ensures the unification of teaching and learning of students concerning: 1) proposed digital templates for various types of traditional classes (lectures, laboratory classes, work in small groups, individual consultations);2) proposed digital tools for conducting educational activities; 3 ) the proposed unified procedure for providing support and assistance to teachers and students; 4) approval of synchronous and asynchronous stages of learning in the framework of the course. Along with this, the flexibility of distance learning was provided by: 1) the ability of the teacher to identify, combine the proposed digital learning tools (Panopto, Canvas, Teams, Vevox); 2) the ability of teachers and students to asynchronously conduct certain stages of educational activities (for instance, browsing presentation materials). Determination of the model of teaching and conducting courses at the level of HEIs solves some problems of distance education, forasmuch as the procedures for conducting classes, support, consultations are pre-defined, and a certain list of infrastructure facilities minimizes obstacles and increases the level of dynamic interaction between a teacher and a student during a crisis.

Rinekso \& Muslim (2020), in the process of studying the use of synchronous online discussion in teaching English at the university, have revealed that this teaching method satisfies students due to the ease of discussion, expression of opinions, task planning, and the ability to get real-time answers to the questions posed. It is synchronicity that provides social support to students during the pandemic and the transition to fully digital learning. In the present research, it was established that the requirement of synchronicity related specifically to discussions (virtual, hybrid, personal) through understanding its positive effects on students' engagement. Dynamic interaction can be ensured by the synchronicity of educational activities as an important requirement of digital higher education, which must be approved by the leadership of the HEI.

The investigation of Carius (2020), has analyzed the transition to emergency distance learning the authors have also included variables related to learning (number of students in groups, synchronous/asynchronous learning mode) and the use of digital technologies. By the way, the idea of promoting organizational factors in the successful implementation of emergency distance learning has been also confirmed in the scientific work. According to the present research, successful planning of the learning process, conducting courses in a crisis and under the conditions of absence of other options for organizing training at HEIs, contribute to the effectiveness of digital models.

\section{Conclusion}

In the course of the research, it has been revealed that technical, technological support for a digital learning model based on a flexible, inclusive approach ensures the unification of teaching and learning of students concerning: 1) proposed digital templates for various types of traditional classes (lectures, laboratory classes, work in small groups, individual consultations); 2) proposed digital tools for conducting educational activities;

Nina, L., Yuzkiv, H., Yanchytska, K., Oksana, N., \& Batchenko, L. (2022). Modern learning models through teacher and student dynamic interaction in HEI towards COVID-19 pandemic condition. International Journal of Health 
3) the proposed unified procedure for providing support and assistance to teachers and students. To provide the effectiveness of the digital learning model and ensure the dynamic interaction of the teacher and the student in the online environment, planning of crises should be used and scenarios for organizing educational activities should be developed. It is the Business Continuity Planning (BCP) framework of the University of Oxford that provides an understanding of the current crisis. The next factor in the effectiveness of training at HEIs during a pandemic is the planning of training courses based on templates developed by the leadership of HEIs. Templates of hybrid, virtual, personal courses provide unified teaching and learning processes, greatly facilitating the interaction of students and teachers. The specific digital learning tools (Panopto, Canvas, Teams, Vevox) facilitate synchronous interaction, while the ability to choose and combine different tools by teachers involves asynchronous.

Acknowledgments

We are grateful to two anonymous reviewers for their valuable comments on the earlier version of this paper. 


\section{References}

Alkhalaf, S., Drew, S., Alghamdi, R., \& Alfarraj, O. (2012). E-learning system on higher education institutions in KSA: Attitudes and perceptions of faculty members. Procedia-Social and Behavioral Sciences, 47, 11991205. https://doi.org/10.1016/j.sbspro.2012.06.800

Andrew, C., \& Pfurtscheller, G. (1996). Event-related coherence as a tool for studying dynamic interaction of brain regions. Electroencephalography and clinical neurophysiology, 98(2), 144-148. https://doi.org/10.1016/0013-4694(95)00228-6

Arianggara, A. W., Baso, Y. S., Ramadany, S., Manapa, E. S., \& Usman, A. N. (2021). Web-based competency test model for midwifery students. International Journal of Health \& Medical Sciences, 4(1), 1-7.

Arora, A. K., \& Srinivasan, R. (2020). Impact of pandemic COVID-19 on the teaching-learning process: A study of higher education teachers. Prabandhan: Indian journal of management, 13(4), 43-56.

Asarta, C. J., \& Schmidt, J. R. (2020). The effects of online and blended experience on outcomes in a blended learning environment. The Internet and Higher Education, 44, 100708. https://doi.org/10.1016/j.iheduc.2019.100708

Bao, W. (2020). COVID-19 and online teaching in higher education: A case study of Peking University. Human behavior and emerging technologies, 2(2), 113-115.

Carius, A. C. (2020). Network education and blended learning: Cyber University concept and Higher Education post COVID-19 pandemic. Research, Society and Development, 9(10), e8209109340-e8209109340.

Chang, C. L., \& Fang, M. (2020). E-Learning and online instructions of higher education during the 2019 novel coronavirus diseases (COVID-19) epidemic. In Journal of Physics: Conference Series (Vol. 1574, No. 1, p. 012166). IOP Publishing.

Cicha, K., Rizun, M., Rutecka, P., \& Strzelecki, A. (2021). COVID-19 and higher education: First-year students' expectations toward distance learning. Sustainability, 13(4), 1889.

Claro, M., Salinas, Á., Cabello-Hutt, T., San Martín, E., Preiss, D. D., Valenzuela, S., \& Jara, I. (2018). Teaching in a Digital Environment (TIDE): Defining and measuring teachers' capacity to develop students' digital information and communication skills. Computers \& Education, 121, 162-174. https://doi.org/10.1016/j.compedu.2018.03.001

Dağ, F., \& Geçer, A. (2009). Relations between online learning and learning styles. Procedia-Social and Behavioral Sciences, 1(1), 862-871. https://doi.org/10.1016/j.sbspro.2009.01.155

Diachenko, A., Vusyk, H., Bielova, Y., Shurdenko, M., \& Titenko, O. (2021). The educational role in COVID-19 terms of ethnodesign graphic function in higher education practical activities. International Journal of Health Sciences, 5(3), 584-593. https://doi.org/10.53730/ijhs.v5n3.2540

Díaz-Campo, J., \& Segado-Boj, F. (2015). Journalism ethics in a digital environment: How journalistic codes of ethics have been adapted to the Internet and ICTs in countries around the world. Telematics and informatics, 32(4), 735-744. https://doi.org/10.1016/j.tele.2015.03.004

Estevez, G. A., Espinosa, A. H. R., \& Rodríguez, D. L. (2019). Design of intervention program for preventing of alcohol misuse in university students. International Journal of Health \& Medical Sciences, 2(1), 33-38.

Ferri, F., Grifoni, P., \& Guzzo, T. (2020). Online learning and emergency remote teaching: Opportunities and challenges in emergency situations. Societies, 10(4), 86.

Gerlich, D., Hirota, T., Koch, B., Peters, J. M., \& Ellenberg, J. (2006). Condensin I stabilizes chromosomes mechanically through a dynamic interaction in live cells. Current biology, 16(4), 333-344. https://doi.org/10.1016/j.cub.2005.12.040

Graham, C. R., Woodfield, W., \& Harrison, J. B. (2013). A framework for institutional adoption and implementation of blended learning in higher education. The internet and higher education, 18, 4-14. https://doi.org/10.1016/j.iheduc.2012.09.003

Iglesias-Pradas, S., Hernández-García, Á., Chaparro-Peláez, J., \& Prieto, J. L. (2021). Emergency remote teaching and students' academic performance in higher education during the COVID-19 pandemic: A case study. Computers in Human Behavior, 119, 106713. https://doi.org/10.1016/j.chb.2021.106713

Lyster, R. (2002). Negotiation in immersion teacher-student interaction. International Journal of Educational Research, 37(3-4), 237-253. https://doi.org/10.1016/S0883-0355(03)00003-X

Lytvyn, V., Akimova, O., Kuznetsova, H., Zenchenko, T., Stepanenko, O., \& Koreneva, I. (2021). The use of synchronous and asynchronous teaching methods in pedagogical education in COVID-19 terms. International Journal of Health Sciences, 5(3), 617-629. https://doi.org/10.53730/ijhs.v5n3.2681

Nina, L., Yuzkiv, H., Yanchytska, K., Oksana, N., \& Batchenko, L. (2022). Modern learning models through teacher and student dynamic interaction in HEI towards COVID-19 pandemic condition. International Journal of Health 
Mishra, L., Gupta, T., \& Shree, A. (2020). Online teaching-learning in higher education during lockdown period of COVID-19 pandemic. International Journal of Educational Research Open, 1, 100012. https://doi.org/10.1016/j.ijedro.2020.100012

Mittal, A., Mantri, A., Tandon, U., \& Dwivedi, Y. K. (2021). A unified perspective on the adoption of online teaching in higher education during the COVID-19 pandemic. Information Discovery and Delivery.

Moore, J. L., Dickson-Deane, C., \& Galyen, K. (2011). e-Learning, online learning, and distance learning environments: Are they the same?. The Internet and higher education,14(2), 129-135. https://doi.org/10.1016/j.iheduc.2010.10.001

Ożadowicz, A. (2020). Modified blended learning in engineering higher education during the COVID-19 lockdown-Building automation courses case study. Education Sciences, 10(10), 292.

Petronzi, R., \& Petronzi, D. (2020). The Online and Campus (OaC) Model as a Sustainable Blended Approach to Teaching and Learning in Higher Education: A Response to COVID-19. Journal of Pedagogical Research, 4(4), 498-507.

Ramírez-Hurtado, J. M., Hernández-Díaz, A. G., López-Sánchez, A. D., \& Pérez-León, V. E. (2021). Measuring online teaching service quality in higher education in the covid-19 environment. International Journal of Environmental Research and Public Health, 18(5), 2403.

Rinekso, A. B., \& Muslim, A. B. (2020). Synchronous online discussion: teaching English in higher education amidst the covid-19 pandemic. JEES (Journal of English Educators Society), 5(2), 155-162.

Rizun, M., \& Strzelecki, A. (2020). Students' acceptance of the Covid-19 impact on shifting higher education to distance learning in Poland. International Journal of Environmental Research and Public Health, 17(18), 6468.

Sá, M. J., \& Serpa, S. (2020). The COVID-19 pandemic as an opportunity to foster the sustainable development of teaching in higher education. Sustainability, 12(20), 8525.

Savinova, N., Berehova, M., Yanchytska, K., Stelmah, N., Biliuk, O., \& Kasatkina-Kubyshkina, O. (2021). ICT role during COVID-19 pandemic in lifelong learning for disabilities. International Journal of Health Sciences, 5(3), 594-604. https://doi.org/10.53730/ijhs.v5n3.2572

Slipchuk, V., Yuzkiv, H., Lutaieva, T., Batechko, N., \& Pisotska, M. (2021). Pedagogical Skills and Communicative Competence of University Teachers during the Classes. Review of International Geographical Education Online, 11(4), 1226-1237.

Thai, N. T. T., De Wever, B., \& Valcke, M. (2017). The impact of a flipped classroom design on learning performance in higher education: Looking for the best "blend" of lectures and guiding questions with feedback. Computers \& Education, 107, 113-126. https://doi.org/10.1016/j.compedu.2017.01.003

Tirziu, A. M., \& Vrabie, C. (2015). Education 2.0: E-learning methods. Procedia-Social and Behavioral Sciences, 186, 376-380. https://doi.org/10.1016/j.sbspro.2015.04.213

Van de Pol, J., \& Elbers, E. (2013). Scaffolding student learning: A micro-analysis of teacher-student interaction. Learning, Culture and Social Interaction, 2(1), 32-41. https://doi.org/10.1016/j.lcsi.2012.12.001

Verawardina, U., Asnur, L., Lubis, A. L., Hendriyani, Y., Ramadhani, D., Dewi, I. P., ... \& Sriwahyuni, T. (2020). Reviewing online learning facing the Covid-19 outbreak.Journal of Talent Development and Excellence, 12(3s), 385-392.

Widana, I.K., Sumetri, N.W., Sutapa, I.K., Suryasa, W. (2021). Anthropometric measures for better cardiovascular and musculoskeletal health. Computer Applications in Engineering Education, 29(3), 550561. https://doi.org/10.1002/cae.22202

Yuzkiv, H. I., Ivanenko, I. M., Marchenko, N. V., Kosharna, N. V., \& Medvid, N. S. (2020). Innovative Methods in Language Disciplines during Profile Training Implementation. International Journal of Higher Education, 9(7), 230-242.

Yuzkiv, H., Slipchuk, V., Batechko, N., Mykhaylichenko, M., \& Vdovychenko, O. (2021). Practical aspects of the application of pedagogical skill and communicative competence of teachers of higher education institutions. Revista on line de Política e Gestão Educacional. 


\section{Biography of Authors}

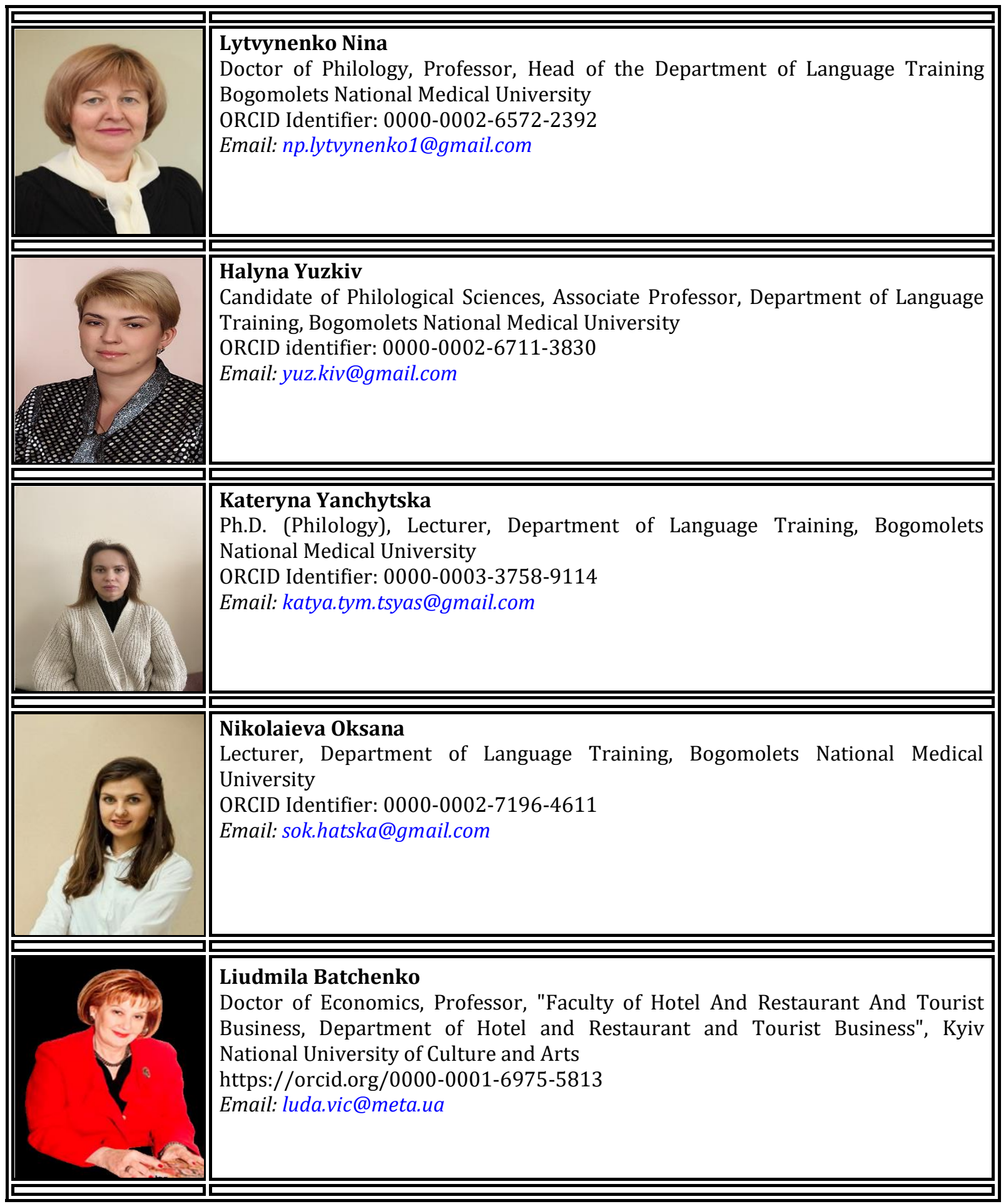

Nina, L., Yuzkiv, H., Yanchytska, K., Oksana, N., \& Batchenko, L. (2022). Modern learning models through teacher and student dynamic interaction in HEI towards COVID-19 pandemic condition. International Journal of Health Sciences, 6(1), 234-243. https://doi.org/10.53730/ijhs.v6n1.3870 